\title{
Developing Inclusive Education Approaches among Stakeholders in Pakistan
}

\author{
Anjum Bano Kazimi*
}

\author{
Syeda Wajiha Kazmi ${ }^{\dagger}$
}

\begin{abstract}
Inclusive Education is defined as a learning environment that promotes the full personal, academic and professional development of all learners irrespective of race class, sexual preference, learning styles and language (NCSNET, 1997). Inclusive Education is a system, an approach, and a way of providing support to special need persons in achieving their life goals with their abilities and potentials. For some it is an ideal state, so implementation of these practices varies at all levels. Development and progress of inclusive education depend on answering many questions: what is the perception people have about it? Why do we need inclusive education? Who needs it? Whose responsibility is this and what to do to achieve the goals of Inclusive Education? Answering these questions needs research. Pasha (2012); Dua and Dua (2017) emphasized the role of stakeholders in promoting Inclusive Education. This study investigated only a fraction of it related to the question of who are the stakeholders in the process of Inclusive Education. They are special-need persons, their parents, general students and their parents, teachers, policy makers and the whole education system. Whether teachers are properly trained to have the right attitude is the key factor in this process (Engage, 2010; UNICEF, 2003). This research has been designed to investigate perception about Inclusive Education and development of Inclusive Education approaches among teachers, parents and administrators of schools through action research. Research was descriptive in nature. Sample of forty-five was purposely selected from teachers, parents and administrators of schools. Data was collected in two stages: initial and final (Pre Test and Post Test) through a structured questionnaire validated through expert opinion to analyze the change in awareness level, skills, and motivation of the sample after conducting a ten-day workshop. The material was selected and workshop was conducted by the field related experts. The findings of this research show a positive and significant change in observation, understanding, identification skills and approach towards special needs, inclusive education and inclusive environment.
\end{abstract}

Keywords: Inclusive education, perception, special needs, teaching approaches.

\section{Introduction}

Inclusive Education is defined by the Salamanca World Conference on Special Needs Education (1994) and was restated in Dakar (paragraph 4). As Inclusive Education meaning that: "Schools should accommodate all children, regardless of their physical, intellectual, social, emotional, linguistic or other conditions. Inclusive education is concerned with identifying and overcoming all barriers to effective, continuous and quality participation in education, particularly during the primary cycle, where a well-documented human right to free participation is widely accepted in World Education Forum Dakar, Senegal

*Iqra University, Pakistan. E-mail: anjum.bano@iuk.edu.pk

${ }^{\dagger}$ Iqra University, Pakistan. E-mail: wajiha.kazmi@iuk.edu.pk 
26-28 April 2000 Education for All 2000 Assessment NUASCO). All developed and developing countries to move and convert segregated special education system to inclusive education (Taylor \& Ringlaben, 2012), so all children without any discrimination can get education together. The system where children with different special needs like hearing, visual, learning, emotional etc. Will get an education, demands a very carefully planned environment, curriculum, and devoted teachers to increase in global demand, parental demand and awareness, the number of special needs children increasing and requirement of professionally trained teachers is also increasing (McHatton \& Parker, 2013).

Researcher's support and show that the strength and quality of education depends on the quality if teachers and their professional training (Davis \& Layton, 2011). If we want to move towards an inclusive system of education, we will need to train all teachers serving in general education to meet the demand of required number of trained teachers. The Professional Competence of Teachers in Inclusive Education. Proper planning and collective efforts of trained teachers can help in bringing enabling educational environment and including all special- needs children in mainstream (Slavit, Nelson, \& Lesseig, 2016).

Inclusive education as assimilation of special children is a basic need of society and one of the primary duties of the state. Globally, education is considered as a basic human right and its responsibility lies with the government in Pakistan free primary education is available in government run schools and also in special schools. All these schools are serving special-need children, but in segregation (Peerzada \& Jabeen, 2014). Pakistan is still far behind in providing inclusive education for special- needs children, and for some it is still just an ideal concept as stated by (Kauffman \& Hallahan, 1995). For the success of any educational system, there are three building blocks: teachers, pedagogy and curriculum; but for Inclusive Education a fourth block is also very important (Chu, 2011) and that is the inclusive environment. The Guidelines for Inclusion (UNESCO 2005) uses four key elements to conceptualize inclusive education: it can be seen as a process; it requires the identification and removal of barriers to learning; it aims to have ALL students achieve results in attendance, participation, and quality learning; for fulfilling a special need of these children providing an environment in which special need children can learn and work with least restrictions. The teacher's role is the most important (Rose, 2007). The whole teaching process revolves around a teacher and proper training develops a positive attitude towards inclusion and special-need persons. (Campbell, Gilmore, \& Cuskelly, 2003; Forlin, 2006; Rose, 2007).

A teacher's attitude, behavior, perception and approach towards special needs are also very important in addition to knowledge. Research indicates that improvement in knowledge and skills creates an impact on a persons approach to his/her work. Successful implementation of inclusive practices depends mainly on teachers' attitudes towards kids with exceptional needs and their inclusion, and teachers' willingness to work with children with special needs in their classrooms (Rakap \& Kaczmarek, 2010). Knowledge of special needs, special-need persons and inclusive education impacts shapes attitude and behavior; it gives insight and observational skills to teachers and parents, which can help them provide a rich inclusive environment for special-needs children. 


\section{Literature Review}

Davis and Layton (2011); Alghazo, Dodeen, and Algaryouti (2003) concluded that a teacher's attitude toward special-need persons and inclusive teaching is one of the most significant elements that affects the success of inclusion process and, by understanding and forming on the attitude, implementation can be bettered. Teachers with more positive attitudes toward inclusion are more likely to adjust their instruction and curriculum to meet individual needs of students (Taylor \& Ringlaben, 2012). Campbell et al. (2003); Panda (2005) say that teachers feel confident and relaxed and are more prepared for inclusive approach if they are properly trained to have a positive attitude towards special persons (Beacham \& Rouse, 2012). Teachers' personal knowledge, self-efficacy, feelings, and attitudes intermingle and impact pre-service teachers' perceptions about their sciences to instruct all children. Various studies have indicated that improper training of teachers and nonprofessional attitude towards inclusive education are major obstacles in the promotion of inclusive education. (Armstrong, Armstrong, \& Barton, 2016; Lancaster \& Bain, 2010) concluded that increased knowledge leads to more positive attitudes, yet though the connection may be quite diminished in a teacher training program. Not only teacher's concern and attitude, but also that of heads of institutes are a very important factor. In Pakistan, the number of private schools is much larger than that of the government schools and the private schools have better facilities and freedom of taking decisions on admission policies, but these institutes are the ones that are negative towards inclusive education (Saad, 2016). On one hand, they do not want to use their facilities for specialneed students and on the other their teachers are also not very positive. Engage (2010), which provided training and sensitized teachers to the rights and needs of children with disabilities, indicated that the attitudes of parents, teachers, politicians, service providers and other community members are the main challenge to inclusive education. Hussain (2012) highlighted the importance of community and parental associations for inclusive education (Rakap, Cig, \& Parlak-Rakap, 2017). Rakap and Kaczmarek (2010) highlighted that willingness to work with special-need children increases positive attitude towards inclusive education. Researches support and show that the strength and quality of education depend on teachers' professional training (Davis \& Layton, 2011). If we want to move towards an inclusive education system, we need to train all teachers serving in general education to meet the demand of required number of inclusive-education-trained teachers. Proper planning and collective efforts of trained teachers can bring a change in educational environment and include all special-needs children in mainstream schools (Slavit et al., 2016).

\section{Methodology}

The research was mixed method and descriptive in nature. Sample of forty-five students was selected purposely from five Government primary schools and five private schools, primary section in Gulshan-e-Iqbal and three special schools; teachers and parents were selected randomly; administrators were selected on availability. In the first phase, review 
of related literature, including documents was done for selection of workshop material. A team of four experts was developed to conduct workshops. One of the selected schools was chosen as the venue of the workshop.

As the first step a ten-day workshop was organized in one of the selected schools with the permission of the principal. Duration was 3 hours per day, in which experts from related fields $\mathrm{w}$ were invited as team members to conduct the workshop. Before starting the workshop sessions, a pretest was conducted through a structured questionnaire. After completion of the workshop, a post test was done to collect data.

\section{Instrument}

The instrument was designed, prepared and validated through the experts' opinion and help. The questionnaire consisted of 22 questions; both close-ended and open-ended questions were included to get data related to the concepts, understanding and approach of the participants towards inclusive education based on the information provided to them through the 30-hour workshop conducted by the experts in the field of special education. Data was analyzed through SPSS.

\section{Results}

\section{T-test Analysis}

Table 1

Paired Samples Statistics

\begin{tabular}{lcccc}
\hline & Mean & N & Std. Deviation & Std. Error Mean \\
\hline Pair 1 PRE_Training & 3.7027 & 40 & 0.60238 & 0.09524 \\
POST_Training & 2.9109 & 40 & 0.59088 & 0.09343 \\
\hline
\end{tabular}

Table 2

Paired Samples Correlations

\begin{tabular}{cccc}
\hline & N & Correlation & Sig. \\
\hline Pair 1 PRE_Training \& POST_Training & 40 & -0.047 & 0.773 \\
\hline
\end{tabular}

Table 3

Paired Samples Test

\begin{tabular}{|c|c|c|c|c|c|c|c|c|c|}
\hline & \multicolumn{9}{|c|}{ Paired Differences } \\
\hline & & Mean & Std. Deviation & Std. Error Mean & $\begin{array}{r}95 \% \mathrm{Co} \\
\text { Interv } \\
\text { Diff }\end{array}$ & $\begin{array}{l}\text { lof the } \\
\text { rence }\end{array}$ & $t$ & df & Sig. (2-tailed) \\
\hline Pair 1 & PRE_Training - POST_Training & 0.79178 & 0.86340 & 0.13652 & $\begin{array}{c}\text { Lower } \\
0.51566\end{array}$ & $\begin{array}{c}\text { Upper } \\
1.06791\end{array}$ & 5.800 & 39 & 0.000 \\
\hline
\end{tabular}




\section{Graphical Representation of Results}

\section{Graphs}

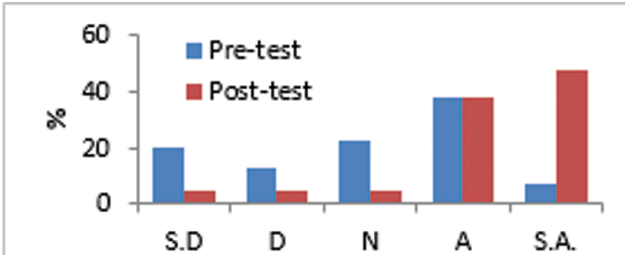

I have knowledge about inclusive...

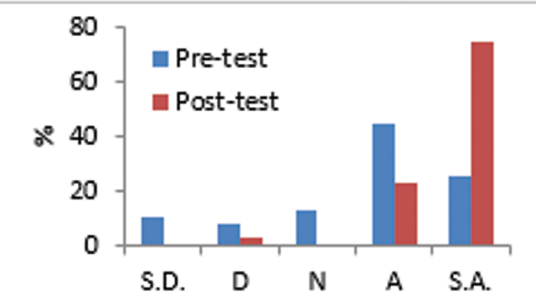

Special need children can get education...

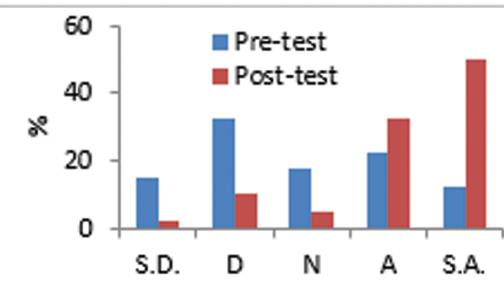

With proper modification all general...

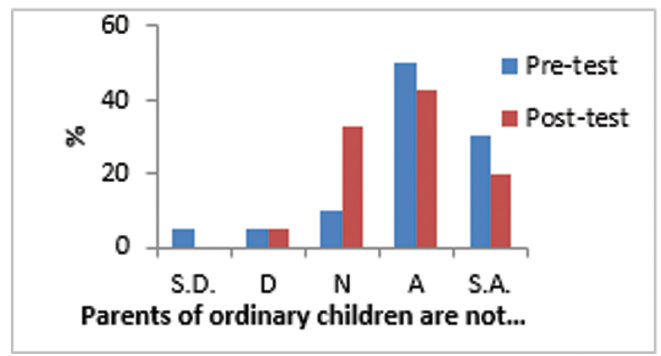

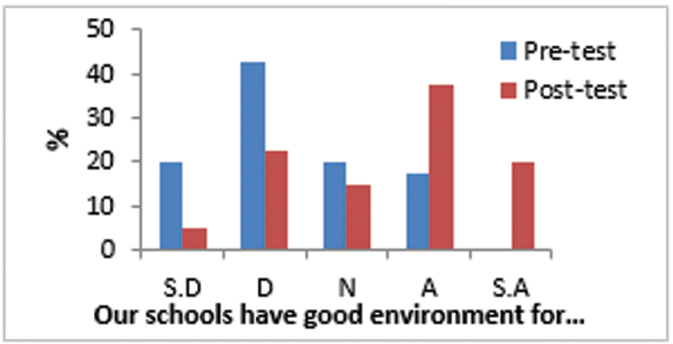
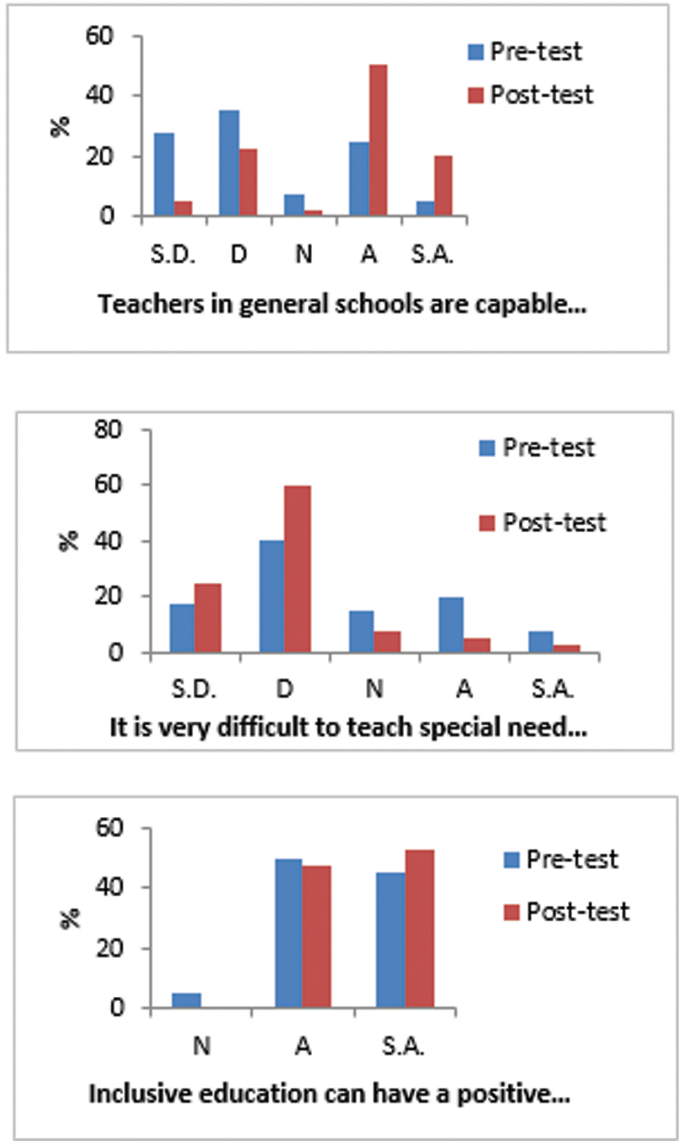


\section{Interpretation}

Results related to the question about having knowledge of inclusive education were quite interesting; in pretest mostly respondent answered that they have knowledge but in posttest fewer agreed that they have knowledge about inclusive education. In response to the question about schools having good environment for inclusive education, results showed $40 \%$ agreed while 30\% disagreed. In answer to the question whether special-need children can get education in general education, the pretest agreement is $20 \%$ while posttest showed that $80 \%$ agreed and strongly agreed. In answer to the question whether teachers in general schools are capable of teaching special-need children, the post-test agreement score is much higher than the pretest. When asked whether with proper modification general schools can be converted into inclusive schools, a very low number was in favor in pretest but a very higher number was in favor in the post test. When asked if it is very difficult to teach special need child/children, a higher number agreed in pretest but disagreed in post test. When asked regarding acceptance of special need children by the parents of ordinary children, results show the positive effect of the training. In response to question that inclusive education can have a positive impact on children with special needs all agreed. In response the question about schools having enough facilities for special-need children, pretest showed a lot disagreed while post test showed that a high number agreed. In answering the question about feeling comfortable with special needs children, nearly all respondents answered agreed or strongly agreed in post-test as compared to the low level of agreement in the pretest.

In answering the question whether all special children can be integrated in general schools, a high number showed agreement, but 20\% still showed disagreement [In pre, or post- test?] In answering the question whether inclusive education can improve the abilities of special needs children, pre and post both results showed agreement. When asked whether general schools can be converted into inclusive schools with proper modification, a higher number were not in favor in pretest but a higher number was in favor in post-test. In response to the question about the abilities of teachers to identify specialneed children in their classes, a great difference was seen in pre and post results. Results are more positive in post-test. In response to the question about their ability to develop an IEP, in pretest higher number showed an inability while in post-test higher number showed ability. In response to the question about using present equipment and facilities for inclusive education after modification, nearly all agreed in post-test though fewer did in the pretest. When asked if it was very difficult to teach special-need child/children, a high number agreed in pretest but disagreed in post-test. When asked if teachers in ordinary schools are willing to teach special-needs children, most people did not agree. When asked regarding acceptance of special needs children by the parents of ordinary children, results moved towards agreement after training. In response to the question whether inclusive education can have a positive impact on children with special needs, all answered yes. 


\section{Descriptive Analysis}

Five open-ended questions were also included in the questionnaire. After analyzing the descriptive answers of the respondents, we concluded that before the training and the exposure to the inclusive education concept and the diversity of special-need children, the respondents listed maximum five categories of special-needs children, but after having knowledge and training, they listed eleven different categories of special needs (McHatton \& Parker, 2013). In response to a question two about special needs, they explained special needs of different categories of special need children and included even minor things. In response to the question what is inclusive education, the respondents presented a very clear concept differentiating it from special and general education.

In response to the question about identifying changes that they can bring to the environment, school environment, helping aids, teaching aids and behavior, requiring everything to be more barrier free and friendly for special needs children, they suggested and identified a long list which shows improvement in their observation and positive change in their attitude toward inclusive education (Croft, 2006). In answer to the query about the importance of inclusive education, respondents explained its economic, social, moral, behavioral and religious grounds, and its importance, in the position of global needs. Their responses indicate that knowledge, skills and exposure or sensitization to special needs can bring change in attitude towards inclusive education (Panda, 2005). In moving towards a more inclusive education system, there is a requirement to train all educators to fulfill the diverse requirements of all apprentices in their classrooms and to work collaboratively with fellow actors.

\section{Conclusion}

After analyzing all the responses of pretest and post-test, it is clearly indicated that training of teachers, parents and head of institutes can bring a very positive change not only in the attitude towards special-need children but also in the approaches towards inclusive education. Although the training provided to the participants of the workshop in this research process was for a short duration (30 hours), its impact can be seen through their responses. Results show that after getting knowledge and exposure to real working situation, all participants accepted that they have special needs children in their class/school; before training they could not identify these children; results also indicated that they all realized that by making modifications in teaching/learning aids in present educational setting they can integrate special-need children in ordinary schools. In short the results reveal that training helped them realize and change their approach towards inclusive education.

\section{Recommendations}

National surveys should be directed at a larger scale to get database on the magnitude and educational condition of kids facing challenges due to types of disability, gender, locality, age and social structure and so forth. Research indicates that inclusive education 
is less costly or cost effective as compared to establishing and running separate specialeducation institutes, especially in Pakistan. Introduction of inclusive education system should be initiated and made compulsory in government as well as in private schools. However, the participation of NGOs and Private Schools Association should be enhanced; they should be motivated to start an inclusive education in their schools. Large scale teacher-training programs should be started in all government schools to provide information and proper training to presently serving teachers. In addition to this, introductory courses about IE should be included in all teacher training courses such as B.Ed., M.Ed. and Montessori. Awareness campaign should be started on a large scale to develop awareness among general public related to the importance and benefits of inclusive education system.

Mass media like T.V., films, posters, radio and net systems should be used to include all sections of the society to motivate for inclusive education. Proper facilities or funds should be provided to schools for making modifications according to inclusive education requirement. Small pilot projects can be started with the help of international consultants or organizations. There is a demand to better coordination between government organizations like the Ministry of Education and Special Education with the ultimate intention of changing the structure of segregated education towards inclusive education. Sections of special training at university level should be delegated the job of training teachers working in a segregated system in government and private schools to train them to implement inclusive education policy. Short courses for teachers can be started in the morning and evening shifts to overcome shortage of trained teachers. There should be legislative support to special persons and special education and it should be made compulsory to admit special-need children in normal schools. The training policy of the government should clearly mark out the schedule to determine the most efficient, pragmatic and cost efficient ways of inducting special-need children in ordinary schools. Universities should encourage research to pinpoint the constraints and difficulties encountered in implementing inclusive education in their jurisdiction. An updated database should be maintained. 


\section{References}

Alghazo, E. M., Dodeen, H., \& Algaryouti, I. A. (2003). Attitudes of pre-service teachers towards persons with disabilities: Predictions for the success of inclusion. College Student Journal, 37(4), 515-522.

Armstrong, F., Armstrong, D., \& Barton, L. (2016). Inclusive education: policy, contexts and comparative perspectives. UK: Routledge.

Beacham, N., \& Rouse, M. (2012). Student teachers' attitudes and beliefs about inclusion and inclusive practice. Journal of Research in Special Educational Needs, 12(1), 3-11.

Campbell, J., Gilmore, L., \& Cuskelly, M. (2003). Changing student teachers' attitudes towards disability and inclusion. Journal of Intellectual and Developmental Disability, 28(4), 369-379.

Chu, S.-Y. (2011). Teacher perceptions of their efficacy for special education referral of students from culturally and linguistically diverse backgrounds. Education, 132(1), 3-15.

Croft, A. (2006). Prepared for diversity? teacher education for lower primary classes in Malawi. Netherlands: Springer.

Davis, R. S., \& Layton, C. A. (2011). Collaboration in inclusive education: A case study of teacher perceptions regarding the education of students with disabilities. National Social Science Journal, 36(1), 31-39.

Dua, V., \& Dua, A. (2017). Inclusive education in Nigeria: Challenges and issues. Indian Journal of Research. Retrieved from https: / / www. worldwide journals.com

Engage. (2010). Inclusive Education in Pakistan: Experiences and lessons learned from the Engage project prepared by; American institute for research 1000 Thomas Jefferson Street NW Washington. Retrieved from https: / / www. worldwide journals.com

Forlin, C. (2006). Inclusive education in Australia ten years after Salamanca. European Journal of Psychology of Education, 21(3), 265-277.

Hussain, K. (2012). Fostering inclusive education in Pakistan: Access and quality in primary education through community school networks.

Kauffman, J. M., \& Hallahan, D. P. (1995). The illusion of full inclusion: A comprehensive critique of a current special education bandwagon. Nandwagon. PRO-ED, Inc., 8700 Shoal Creek Blvd Austin, TX 78757-6897.

Lancaster, J., \& Bain, A. (2010). The design of pre-service inclusive education courses and their effects on self-efficacy: A comparative study. Asia-Pacific Journal of Teacher Education, 38(2), 117-128.

McHatton, P. A., \& Parker, A. (2013). Purposeful preparation: Longitudinally exploring inclusion attitudes of general and special education pre-service teachers. Teacher Education and Special Education, 36(3), 186-203.

Panda, P. (2005). Responsiveness of pre-service teacher education programme towards inclusive education in India: Appraisal of curriculum dimensions and practices. In National council of educational research and training paper presented at the inclusive and supportive education congress.

Pasha, S. (2012). Readiness of urban primary schools for inclusive education in Pakistan. Journal of Research E Reflections in Education, 6(2), 113-128. 
Peerzada, S. M., \& Jabeen, M. (2014). Impact of teachers' subject matter knowledge and behaviour on students' performance. Journal of Research $\mathcal{E}$ Reflections in Education, 2(2), 154-162.

Rakap, S., Cig, O., \& Parlak-Rakap, A. (2017). Preparing preschool teacher candidates for inclusion: Impact of two special education courses on their perspectives. Journal of Research in Special Educational Needs, 17(2), 98-109.

Rakap, S., \& Kaczmarek, L. (2010). Teachers' attitudes towards inclusion in Turkey. European Journal of Special Needs Education, 25(1), 59-75.

Rose, R. (2007). Special educational needs in inclusion primary classroom. London: Paul Chapman.

Saad, I. (2016). Education in Pakistan: Perspective, failures and prospects. Journal of Education E Social Sciences, 4(1), 30-50.

Slavit, D., Nelson, T. H., \& Lesseig, K. (2016). The teachers' role in developing, opening, and nurturing an inclusive stem-focused school. International Journal of STEM Education, 3(1), 1-17.

Taylor, R. W., \& Ringlaben, R. P. (2012). Impacting pre-service teachers' attitudes toward inclusion. Higher Education Studies, 2(3), 16-23.

UNICEF. (2003). UNICEF's Upstream Work in Basic Education and Gender Equality 20032012. 